\title{
Działalność polskich architektów na południowo- -wschodniej Ukrainie na przełomie XIX i XX w. na przykładzie Jekaterynosławia
}

\section{Activities of Polish architects in south-eastern Ukraine at the turn of the $19^{\text {th }}$ and $20^{\text {th }}$ centuries based on the example of Ekaterinoslav}

\begin{abstract}
Streszczenie
Wraz z procesami odrodzeniowymi, jakie zaszły na Ukrainie po 1991 r. i po uzyskaniu przez nią niepodległości, pojawiły się możliwości odrodzenia kultur mniejszości narodowych. Autorka upublicznia i omawia ukryte wcześniej lub zakazane, a wskutek czego mało znane fakty. Celem niniejszego opracowania było wskazanie obecności dziedzictwa architektów polskich na południowym wschodzie Ukrainy. Kreśląc tło historyczne, autorka prezentuje rys architektoniczny regionu Azowskiego Przeddnieprza. Przykładem budowli z tamtego okresu, której poświęca szczególną uwagę, jest kościół pw. św. Józefa w Dnieprze.
\end{abstract}

Słowa kluczowe: tożsamość, Polonia, Ukraina, pamięć kulturowa, polscy architekci

\begin{abstract}
Along with the revival processes that took place in Ukraine after 1991 and after it gained independence, there were opportunities for the revival of national minority cultures. The author publishes and discusses previously hidden or forbidden, and therefore little-known facts. The aim of this study was to indicate the presence of the heritage of Polish architects in the south-east of Ukraine. Drawing the historical background, the author presents an architectural outline of the AzovPrzednieper region. An example of a building from that period, which he devotes special attention to, is the church of st. Joseph in the Dnieper.
\end{abstract}

Keywords: identity, Polish diaspora, Ukraine, cultural memory, Polish architects 


\section{WPROWADZENIE}

Wraz z procesami odrodzeniowymi, jakie zaszły na Ukrainie po 1991 r. i po uzyskaniu przez nią niepodległości, pojawiły się możliwości odrodzenia kultur mniejszości narodowych. Autorka upublicznia i omawia ukryte wcześniej lub zakazane, a wskutek czego mało znane fakty. Możliwość ich rozpowszechnienia pojawiła się dopiero w wyniku zmian politycznych. Na Ukrainie zaczęły odradzać się kultury narodowościowe, w tym kultura polska. Artykuł omawia kwestię nurtu odrodzenia kultury polskiej na południowo-wschodniej Ukrainie. Obszar stanowiący zakres terytorialny przedstawionych badań zamieszkiwany jest przez ponad 130 mniejszości narodowych, w tym stosunkowo nieliczną mniejszość polską, żyjącą w dużym rozproszeniu. Znaczna część badań i prac naukowych poświęconych kulturze i twórczości polskich mniejszości narodowych dotyczy Polaków zamieszkujących takie kraje jak: USA, Kanada, Niemcy, Wielka Brytania, Francja, Kazachstan, Rosja, gdzie żyją one w większych skupieniach. Problematyka śladów polskich i ich kultury w krajach Europy i Ameryki szczególnie aktywnie rozwijana była w II połowie XX w. przez teoretyków Z. Bokszańskiego (2015) oraz J. Muchę (1996, 1999). Badania w tym zakresie stanowią znaczną część dorobku kulturalnego tego obszaru Ukrainy (Babiński, 1997; Dzwonkowski, 2000). Tematowi Polaków na południowym wschodzie Ukrainy, gdzie znajdują się obecnie obwody zaporoski i dniepropietrowski, poświęcono w opracowaniach naukowych znacznie mniej uwagi, a tematyka, pomimo istotnego wkładu takich badaczy, jak H. Krasowska (2012), L. Suchomłynow (2008), A. Bonusiak (2014), G. Babiński (2005), J. Ricoeur (1992), pozostaje wciąż niewyczerpana. Wyżej wymienione opracowania skupiały się na zachowaniu oraz przejawach tożsamości polskiej oraz na czynnikach kulturowych wywierających na nią wpływ. Pomijały one również zabytki związane z architekturą o polskim rodowodzie.

Rozpatrując problematykę architektury i zabytków Ukrainy, często spotkać można odwołanie do rozwoju urbanistycznego architektury na Ukrainie w odniesieniu do konkretnych okresów historycznych, w tym bardzo często czasów radzieckich: Y. Gubkina (2020), S. Smolenskaya (2017) i N. Kondel-Perminova (2009) piszą o epoce radzieckiej awangardy; E. Cherkasova (2008) wspomina o problematyce zachowania spuścizny funkcjonalizmu mieszkaniowego, na przykład we Lwowie (Remeshylo-Rybchynska, Baev, Rybchynsky, 2013); N. Antonenko (2019; Atonenko, Ohrona, 2020) przywołuje w swoich badaniach aktualną problematykę zabytków architektury nowoczesnej w kontekście kultury architektonicznej II połowy XX w. Powyższe badania rozpatrują architektoniczne dziedzictwo Ukrainy (w tym dziedzictwo okresu radzieckiego) oraz nakreślają kryteria uznawania obiektów za zabytkowe, co ma duże znaczenie w aspekcie szans na ochronę zabytkowych obiektów. Temat ten rozpatruje m.in. V. Pavlo (2013). Jak można zauważyć na przykładzie przytoczonej literatury, istnieje tendencja pomijania tematu wkładu twórców mniejszości narodowych w architektoniczne dziedzictwo Ukrainy. Temat odrodzenia polskiej kultury oraz dziedzictwa powstałego w wyniku działalności polskich architektów na Ukrainie bardziej rozpowszechniony jest w jej zachodniej i centralnej części, np. we Lwowie 
czy w Kijowie. Potwierdzają to przykłady znanych na całym świecie budynków: Opera Lwowska Zygmunda Gorgolewskiego, Dom z chimerami Władysława Horodeckiego (Kijów) oraz kościół pw. św. Mikołaja w Kijowie. Działalności Władysława Horodeckiego poświęcono wiele prac oraz wydawnictw, wśród których warto wymienić materiały pokonferencyjne VI Ogólnoukraińskiej Konferencji Naukowej z okazji 150 rocznicy urodzin W. Horodeckiego (2015), na której to rozważane były takie tematy jak jego spuścizna twórcza - N. Dyomin (2015: 58), Y. Ivasho (2015: 84), aspekty estetyczne - K. Gonczarowa (2015: 52), we współczesnej edukacji architektonicznej - O. Szaparenko (2015: 195) oraz w architekturze nowoczesnej - A. Korowkina (Korowkina 2015: 107). Polski wątek w wielokulturowej mozaice południowo-wschodniej części Ukrainy przejawia się w zagadnieniach formowania się tożsamości, a działalność polskich architektów na tym terenie jest praktycznie nieznana. Twórczy dorobek Polaków na tych terenach w dziedzinie sztuki jest istotny, a dziedzictwo kulturowe w zakresie architektury stworzonej przez Polaków w czasach caratu rosyjskiego nie zostało wystarczająco rzetelnie ujęte w żadnym z opracowań naukowych.

W związku z wyżej wspomnianym brakiem dokładnych opracowań naukowych stosownym wydaje się przybliżenie tematu mało znanej działalności polskich architektów na południowo-wschodniej Ukrainie na przełomie XIX i XX w. oraz nakreślenie wpływu wiedzy historycznej na odrodzenie polskiej tożsamości kulturowej na tym obszarze. Najistotniejszymi czynnikami, które wpływają na stan poczucia tożsamości, są: wiedza o swoich korzeniach, kultura i religia. W omawianym przedziale historycznym i regionie największym ośrodkiem miejskim był Jekaterynosław (obecnie Dniepr), założony jako południowa stolica Imperium Rosyjskiego. Cały region charakteryzował się wówczas wielokulturowością, co sprawia, że stanowi on dobry przykład do obserwacji zachodzących wówczas procesów kulturowych i kulturalnych.

Metodologia stosowana w niniejszym artykule obejmuje kwerendę archiwalną i analizę źródeł historycznych, a także badania terenowe i badania in situ autorki.

\section{TŁO HISTORYCZNE}

Ukraina południowo-wschodnia, nazywana również Azowskim Przeddnieprzem, obejmuje tereny dawnych tzw. Dzikich Pól. Stanowi ona obszar interesujący z punktu widzenia swojej wielokulturowości, ponieważ zamieszkuje ją ponad 130 mniejszości narodowych, w tym również mniejszość polska. Ukraina południowo-wschodnia była i jest do dziś obszarem pogranicza kulturowego. Historia wielokulturowości tego regionu jest długa i sięga czasów caratu, polityki kolonizacyjnej, zwłaszcza od II połowy XVIII w. Stepy przydnieprzańskie, zwane Dzikimi Polami, weszły w skład Imperium Rosyjskiego w 1775 r. Na tych terenach ścierały się wpływy polityczne caratu rosyjskiego (a potem polityki radzieckiej) z tożsamością ludności mieszkającej na tych obszarach: Ukraińców, Rosjan, Bułgarów, Greków, Tatarów, Niemców, Polaków, Czechów, Białorusinów, Litwinów, Asyryjczyków, Karaimów i innych narodów. W 1764 r. caryca Katarzyna 
II utworzyła gubernię noworosyjską, w której obrębie znalazł się obecny obwód dniepropietrowski i zaporoski. Jekatyrynosław stał się sercem przemysłowym i kulturalnym guberni.

Życie Polaków na terenach Ukrainy południowo-wschodniej różniło się znacznie od życia Polaków z zachodniej Ukrainy, która do 1939 r. należała do Rzeczpospolitej. Obecność Polaków na tym terytorium wynikała z przesiedlenia ich przez carycę Katarzynę II.

Okres XVII-XVIII w., a zwłaszcza poczqtek lat 70. XVIII w. oraz I połowa XIX w., charakteryzuje się rozwojem ośrodków przemysłu i wspierajqqca go politykq caratu rosyjskiego [...]. Dokonywano [wówczas - przyp. red.] przymusowych przesiedleń drobnej szlachty polskiej i włościan oraz przesiedlania najemników do pracy w przedsiębiorstwach przemysłowych [...], zsyłano również na te tereny uczestników powstań. Jednym z głównych nurtów polityki caratu w tym okresie było kierowanie cudzoziemców na południowq Ukrainę, stepy Przyazowia i na Krym. Bułgarzy, Niemcy, Czesi byli zachęcani do zagospodarowania nowego kraju (Pavliuk, 2019: 206).

Polityka rozmaitych ulg dla (dobrowolnych) przesiedleńców spowodowała szybki wzrost liczby mieszkańców południowo-wschodniej części Imperium Rosyjskiego.

Wielu Polaków trafiło na ziemie ukraińskie przymusowo jako zesłańcy po rozbiorach Polski. Już pod koniec wieku XVIII przybyli na te ziemie polscy zesłańcy konfederaci, przy czym największa ich liczba przypada na wiek XIX, po powstaniu listopadowym w 1830 r. i styczniowym z 1863 r. Byli to ich uczestnicy, ale też członkowie tajnych organizacji patriotycznych, a w ostatnich latach XIX i początkach XX w. zwolennicy ruchów rewolucyjnych. Niekiedy także byli to pracownicy z Polski przesiedleni do pracy w zakładach przemysłowych - hutach, manufakturach, gorzelniach ${ }^{1}$ czy innych $^{2}$ (Pavliuk, 2019).

Obszar ten należy do regionów, które przekształciły się z obszarów niezagospodarowanych w tereny o wysokim poziomie industrializacji z szybko rozwijającym się przemysłem. Wśród nich wymienić należy: Zagłębie Donieckie i przylegające do niego terytorium Ukrainy Naddnieprzańskiej z centrami w Jekaterinosławiu i Aleksandrowsku (obecne Zaporoże).

W ten sposób osiedlili się w tym rejonie Polacy i ich potomkowie z zachodnich kresów Imperium Rosyjskiego ${ }^{3}$. Zsyłkom towarzyszyły też przymusowe przesiedlenia chłopów i robotników, których Imperium potrzebowało do celów militarnych i gospodarczych.

Emigracja robotników polskich na te tereny była zwykle procesem żywiołowym. Podejmowali oni często decyzje na własne ryzyko, mając ograniczoną wiedzę o warunkach pracy i nowym miejscu osiedlenia. Znane są też fakty wyjazdu robotników z Królestwa w sposób zorganizowany. Zazwyczaj działo się to wówczas, gdy zakładano tam filie. W takich przypadkach na koszt fabryki przewożono część załogi, najczęściej robotników wykwalifikowanych (Krasowska, 2012: 74).

1 Na przykład w Kamieńsku, obwód dniepropietrowski.

2 Na przykład w Zakładach Mechanicznych Bormann, Szwede i S-ka, które przeniesiono z Warszawy do Aleksandrowska (obecne Zaporoże).

3 Głównie z Wileńszczyzny i Białorusi oraz obecnej Ukrainy centralnej. 


\section{RYS ARCHITEKTONICZNY}

Wartym uwagi w zakresie architektury jest region Azowskiego Przeddnieprza. Jekaterynosław na przełomie XIX i XX wieku przekształcił się w duże miasto przemysłowe, w którym wzniesiono wiele wielkokubaturowych obiektów użyteczności publicznej, a w budownictwie mieszkaniowym coraz powszechniejsze stawały się wielopiętrowe segmentowe budynki mieszkalne. Jekaterynosław założono jako miasto klasycystyczne w I połowie XIX w., w okresie rozkwitu rosyjskiego klasycyzmu, z szeroko stosowanymi portykami, frontonami i galeriami. Klasycyzm panujący na przełomie XVIII i XIX w. został zastąpiony później przez eklektyzm z charakteryzującą go różnorodnością trendów stylistycznych i zasadą „swobody wyboru" stylu i z poszanowaniem zależności formy od przeznaczenia budynku. Eklektyzm w Jekaterynosławiu obejmuje m.in. styl rosyjski, neoklasycyzm, romantyzm narodowy oraz neogotyk. Przykładem budowli w tym ostatnim stylu może być Dom Gubernatora - dwukondygnacyjny budynek wzniesiony w latach 30. XIX w. przez architekta Nikołaja Nasedkina. Jest on przykładem odmiany stylu rosyjskiego zorientowanego na architekturę ludową. Największym budynkiem publicznym w tymże stylu był dworzec kolejowy. Jego bryłę wyznaczały wieże. Zdobiły go podwieszone łukowate otwory i inne charakterystyczne detale. W tym okresie w Jekaterynosławiu dominował jednak tzw. eklektyzm bez stylu. Styl projektowanych obiektów był wybierany dowolnie, w dużej mierze zależnie od upodobań klienta lub architekta. Od końca XIX w. do I połowy XX w. szczególne miejsce zajmował tzw. styl ceglany. Nawiązywał on do całego nurtu i determinował charakter rozwoju całej historycznej części miasta poprzez eklektyczne fasady tworzone w duchu „bez stylu”. Elewacje budynków dowolnie łączyły motywy wywodzące się ze szkół architektonicznych: staroruskiej, gotyckiej, bizantyjskiej, romańskiej, w tym motywy klasycyzmu, romantyzmu, neorenesansu. W ostatniej ćwierci XIX w. na budynkach Jekaterynosławia pojawiały się bardzo ciekawe i różnorodne elementy zdobnicze. Charakterystyczną cechą tamtejszej szkoły budowlanej były słynne ręcznie formowane cegły figurowe. Wykonywano z nich najróżniejsze detale architektoniczne: portale drzwiowe, cokoły i gzymsy, pilastry, kapitele, półkolumny, a także złożone formy zdobnicze. W Jekaterynosławiu wśród detali elewacyjnych typu zoomorficznego często spotykane są głowy Iwów, przeważają one pod względem liczby „zwierzęcych” wizerunków na elewacjach domów.

Na początku XX w. w architekturze Jekaterynosławia pojawiły się budowle w stylu secesyjnym. Do tego stylu z cechami klasycyzmu należy np. Teatr Zimowy, zbudowany w 1907 r., zaprojektowany przez architektów F. Bulatsela i A. Petrovetsky'ego, lub na przykład jedno z najsłynniejszych dzieł Aleksieja Beketowa - budynki Wyższej Szkoły Górniczej (1899-1912), zbudowane w stylu secesyjnym, a ponadto budynek administracji kolei PKP (1905-1907). W stylu ukraińskiej secesji powstał tzw. Dom Crennikowa (obecnie hotel „Ukraina”), pięciopiętrowy kompleksowy budynek autorstwa W. Chrennikowa, Chojnawskiego i petersburskiego architekta P. Fetisowa (niestety obecnie częściowo zmieniony). Jego charakterystycznymi 
cechami są białe ściany, bogactwo majoliki, wielobarwne panele i witraże na elewacji głównej i bocznej, baszty i iglice - budynek został przemyślany i opracowany w jednym stylu, co oznaczało nadanie mu niezwykle monumentalnego charakteru, ale też wyróżnienie elementów ukraińskiego folkloru.

Na początku XX w. mennonita Dietrich Thyssen pozostawił wyraźny ślad w architekturze Jekaterynosławia. W mieście powstało kilka budynków w stylu angielskiej secesji. Thyssen używał różnych wersji stylu secesyjnego, przede wszystkim angielskiej odmiany. Projektował głównie dwory i kamienice. Opanowując techniki różnych wersji stylu secesyjnego, swoimi pracami wzbogacił paletę architektoniczną miasta.

Tym, co przyciągało Polaków, była dynamiczność rozwoju gospodarczego południowo-wschodniej Ukrainy w II połowie XIX w. Zachęcająco działał fakt, iż absolwentom różnych cesarskich uczelni architektonicznych - Cesarskiej Akademii Sztuk Pięknych i Instytutu Inżynierów Cywilnych w Petersburgu, oferowano posady m.in. w miastach Ukrainy Lewobrzeżnej (inaczej Zadnieprza) (Omilanowska, Bilewicz, 2013: 300). Pojawienie się Polaków na tych terenach miało istotny wpływ na wielokulturowość Imperium Rosyjskiego.

Gubernialne miasto Jekaterynosław stało się obszarem, z którym ściśle powiązane są losy polskich rodów, np. Chormańskich, Brodnickich. Jednym z rodów o tradycjach architektonicznych, mieszkającym i pracującym w Jekaterynoslawiu, byli Brodniccy. Ród Brodnickich, a w szczególności architekci Albert i jego syn Leonid (Leon), odegrał bardzo istotną rolę w kształtowaniu struktury miejskiej Jekaterynosławia, jak również całej jekaterynosławskiej guberni w XIX i XX w. Albert Brodnicki jako gubernialny architekt stworzył wiele słynnych obiektów, w tym w 1860 r. Pałac Spotkań Szlachty (obecnie Pałac Studentów) oraz kościół rzymsko-katolicki św. Józefa. Nadzorował też, jako autor, w latach 1872-1874 prace budowlane przy kompleksie seminarium duchownego. Jego syn Leon Brodnicki był również gubernialnym i diecezjalnym architektem w latach 1890-1900 (Szrub, 2019) i stworzył między innymi w latach 1900-1902 Pałac Gubernialnego Urzędu Ziemskiego, w 1905 r. Dom Jawornickiego - znaczący obiekt dla neoklasycyzmu i eklektyzmu, gmach Głównego Urzędu Pocztowego, czyli tzw. Pocztę Główną (Gorodczenko, 2015) w zespole razem z architektami Stanisławem Charmańskim i Aleksandrem Mikłaszewskim.

W Jekaterynosławiu mieszkał i pracował także inny istotny dla dziedzictwa kultury ród polskich architektów. Założyciel rodu - architekt Edward Julian Charmański, po ukończeniu Szkoły Budownictwa w Petersburgu osiedlił się wraz z żoną w Jekaterynosławiu (1859) (Księga pamiq̨tkowa Inżynierów Cywilnych Polaków wychowanków Instytutu Inżynierów Cywilnych w Petersburgu, 1937: 57), gdzie otrzymał posadę pomocnika architekta w gubernialnej komisji drogowo-budowlanej. Jego synowie również byli architektami: Zdzisław Marian i Stanisław Antoni. W 1890 r. Zdzisław Marian przeniósł się do Charkowa, gdzie od 1896 do 1917 r. pracował na stanowisku ziemskiego inżyniera gubernialnego oraz kierował Wydziałem Technicznym Urzędu Miejskiego (Polakowa, 2014: 136). Drugi syn, Stanisław Antoni Charmański, urodzony w 1861 r., po studiach w Petersburgu powrócił do rodzinnego miasta 
i w 1887 r. został zatrudniony na stanowisku młodszego inżyniera wydziału budowlanego jekaterynosławskiego Zarządu Gubernialnego. Pracował od lat 90. XIX w. do października 1914 r. na stanowisku inżyniera gubernialnego. Był autorem projektów wielu budynków użyteczności publicznej, w tym Audytorium Komisji Czytań Narodowych, a w 1904 r. dokonał rozbudowy miejscowego kościoła katolickiego.

Znaczny wpływ na architekturę tego regionu wywarł również architekt Aleksander Mikłaszewski, który tworzył na przełomie XIX-XX w. Pracując w dziedzinie architektury ponad 25 lat, odznaczył się przede wszystkim unikatowością rozwiązań. Za najwybitniejsze działo architekta uważa się powszechnie cerkiew Kazańską, zaprojektowaną w 1906 r., wybudowaną w latach 1907-1913, a następnie zniszczoną przez władze radzieckie w 1936 r. (dombrovskii_a, 2012).

Na szczegółowe przedstawienie zasługuje również jedna z lokalnych ikon architektury, stworzonych przez architektów Polaków, która zachowała się do czasów współczesnych. W Jekaterynosławiu już w 1842 r. miejscowa społeczność katolicka zgłaszała postulaty do władz o zgodę na budowę kościoła. Zezwolenie zostało wydane 11 maja 1844 r. Projekt kościoła został wykonany przez dwóch architektów. Pierwotny projekt kościoła autorstwa Alberta Brodnickiego (Czaban, 2007) nie został zatwierdzony przez Komitet Techniczno-Budowlany Ministerstwa Spraw Wewnętrznych. Oprócz wątpliwości dotyczących architektury kościoła pojawiły się poważne zastrzeżenia do wytrzymałości konstrukcji przyszłej budowli. W rezultacie projekt został znacznie zmieniony przez członka Komitetu, architekta Piotra Merkulowa. Zwiększono nieco szerokość kościoła, natomiast zmniejszono wysokość wieży dzwonnicy4. Obniżono również wysokość nawy kościoła oraz uproszczono fasadę, przez co była ona zbliżona do stylu romańskiego. W dniu 16 lipca 1869 r. nowy projekt architektoniczny został zatwierdzony przez Ministerstwo Spraw Wewnętrznych (Starostin, 2011b). Budowę kościoła pw. św. Józefa rozpoczęto 17 czerwca 1872 r., a ukończono w 1877 r., konsekrowano go w 1878 r. (Starostin, 2011b). Kościół został zlokalizowany w centrum miasta. Dla architektury Jekaterynoslawia ówczesnych czasów architektura kościoła była bardzo nietypową. Obok dwupiętrowych budynków pojawiła się potężna budowla z dwiema masywnymi strzelistymi wieżami, które były widoczną subdominantą w panoramie miasta. Zbudowany kościół pozostawał w stylu neogotyckim, lecz z wykorzystaniem elementów stylu romańskiego. W środku uwagę przyciągały dwa potężne, ostre łuki. Wnętrza ozdobiono unikatowymi freskami. Niektóre z nich zachowały się do dziś, mimo iż w czasach ZSRR świątynia była zamknięta i wykorzystywana w różnych celach, w tym również jako magazyn. Łatwo zauważalnym śladem polskiej architektury w mieście są fragmenty polskich inskrypcji, które można znaleźć na budynkach.

Kościół jako centrum życia katolickiego skupiał miejscowych Polaków oraz katolików innych narodowości (Szrub, 2019). Ze względu na zwiększającą się liczbę wiernych w dniu

4 Całkowita wysokość wraz z iglicami pozostała niezmieniona. 
22 lutego 1900 r. Ministerstwo Spraw Wewnętrznych zaaprobowało projekt rozbudowy kościoła autorstwa architekta gubernialnego Stanisława Charmańskiego. W ramach projektu budowla została rozszerzona o nawy boczne. Przebudowano również prezbiterium. Prace zakończono w 1910 r. Neogotycki kościół łączył w sobie nowe inspiracje. Fronton świątyni od strony ulicy był ozdobiony dwoma wysokimi wieżami, w których umieszczono dzwony. Nad głównym wejściem zlokalizowano portal, a nad nawą ustawiono figurę anioła z krzyżem. Świątynia miała pierwotnie tylko jedną nawę oświetloną wysokimi, strzelistymi oknami, zakończoną absydą ołtarzową. Nad ołtarzem na dachu była przewidziana w projekcie wysoka, ażurowa wieża.

Po rewolucji bolszewickiej wszelkie przejawy religijności były zwalczane, a osoby religijne prześladowane. W 1928 r. parafię św. Józefa zlikwidowano, a w przejętym budynku kościoła otwarto zakład szklarski. Wszelka własność kościoła i sztuka sakralna uległy zniszczeniu. Podczas okupacji hitlerowskiej w 1942 r. przez krótki okres w kościele odprawiano msze święte dla włoskich żołnierzy, w których uczestniczyła też nieliczna grupa miejscowych katolików. Po wojnie budynek kościoła uległ ponownej sowietyzacji. W wyniku rekonstrukcji w latach 1949-1950 styl neogotycki zastąpiono stalinowskim neoklasycyzmem

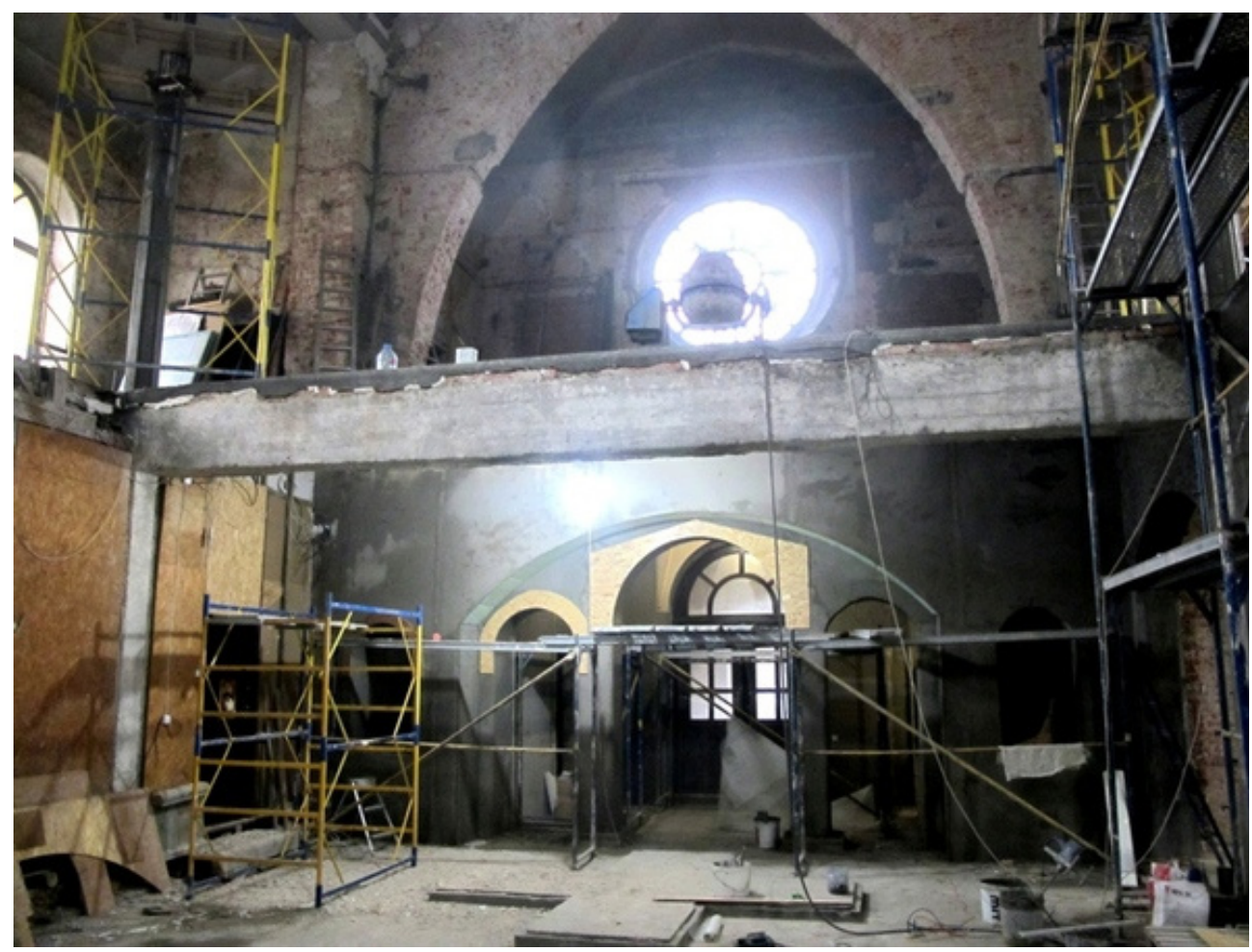

II. 1. Kościół pw. św. Józefa w Dnieprze w momencie przekazania go parafii, 2009 (Gonczenko, 2013) 
z kolumnami i półokrągłym balkonem, dzięki którym, w zamierzeniu, budynek miał nie kojarzyć się ze świątynią. W latach 50. mieściła się tam biblioteka miejska, a potem sale sportowe (Starostin, 2020).

Po upadku ZSRR i uzyskaniu przez Ukrainę niepodległości zaczęły rozwijać się kultury mniejszości narodowych, co miało szczególnie duże znaczenie dla południowo-wschodniej części państwa. Możliwość powrotu do kulturowych źródeł tożsamości, jaka zaistniała po odzyskaniu autonomii przez Ukrainę, zrodziła możliwość odzyskania swoich korzeni i pielęgnacji swojej tożsamości. Rozwój kultury polskiej został zapoczątkowany przez aktywistów, którzy wbrew przeciwnościom losu zachowywali swoją polską tożsamość i jako pierwsi na terenach posttotalitarnych gromadzili wokół siebie ludzi, odtwarzali parafie, zapraszali księży i zakładali pierwsze stowarzyszenia kultury polskiej. Dopiero w 2009 r. parafia dniepropetrowska wygrała walkę o kościół i stała się jego prawnym właścicielem. Obecnie kościół posiada kopuły, dzwon, fasadę odnowioną na podstawie zdjęć historycznych, a przed kościołem postawiony został pomnik św. ojca Pio, co nadaje przestrzeni wokół kościoła niepowtarzalny charakter.

Do znaczących dzieł architektonicznych stworzonych przez polskich architektów można zaliczyć również obiekty zaprojektowane przez innych wymienionych w tym artykule polskich architektów, którzy działali na tym obszarze, ale większość z nich nie zachowała się i wymagałoby to dalszych, szerzej zakrojonych badań historycznych i archeologicznych.

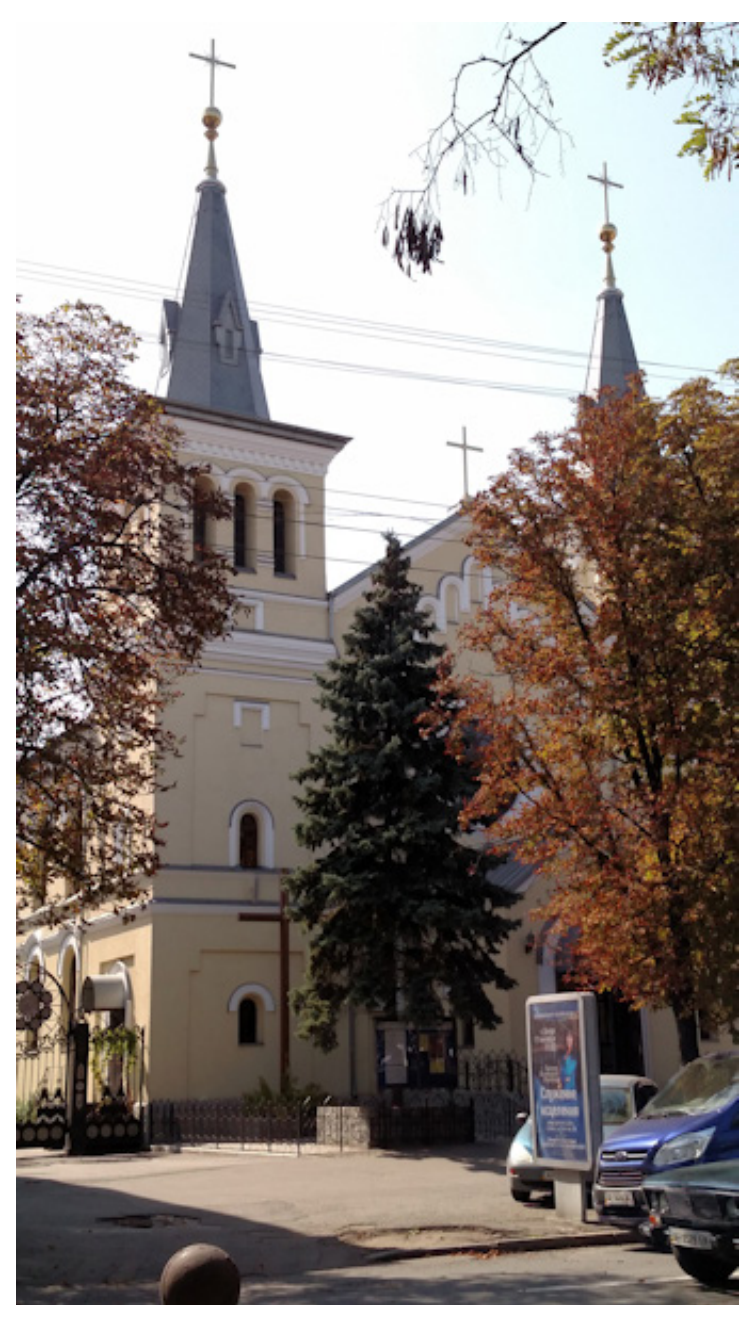

II. 2. Kościół pw. św. Józefa dziś (2017 r.). Fot. autor 


\section{PODSUMOWANIE}

Celem niniejszego opracowania było wskazanie niezwykle rzadko jak dotąd ujmowanej w badaniach (zarówno polskich, jak i ukraińskich) obecności dziedzictwa architektów polskich na południowym wschodzie Ukrainy. Istotnym wydaje się być, iż działali oni w wielokulturowym środowisku wśród znanych twórców, jak Bieketow, Thyssen, Fetisow i inni. W wielokulturowe środowisko Jekaterynosławia na przełomie wieków wymienieni w tym artykule architekci Polacy wnieśli swój wkład i zróżnicowali koloryt w mozaice architektonicznej tego miasta. Działalność polskich architektów nie była bardzo duża i trzeba nadmienić, że zachowała się jej jedynie część. Niezachowane obiekty wymagałyby dalszej szerokiej analizy materiałów historycznych. Jest to utrudnione ze względu na fakt, iż znacząca część archiwów uległa zniszczeniu w wyniku działań wojennych i politycznych. W Jekaterynosławiu z omawianego okresu historycznego pozostał tylko jeden kościół - pw. św. Józefa, i właśnie z tego powodu skupiono się na opisaniu jego skomplikowanej historii odrodzenia. Ukazuje on modelowe skutki wynaradawiającej polityki radzieckiej. Kultura religijna odgrywa znaczną rolę w formowaniu się tożsamości narodowej, a ponowne powstanie kościoła świadczy o przejawach odrodzenia polskości. Nie był on typową budowlą sakralną dla prawosławnej południowo-wschodniej Ukrainy czasów caratu i świadczą o tym cechy kościoła rzymskokatolickiego, których władza radziecka skutecznie starała się pozbawić obiekt, niszcząc kopuły i przeprojektowując elewacje. Odbudowany i przywrócony do pierwotnej formy kościół znów wyróżnia się wśród zabudowy miasta swymi charakterystycznymi wieżami i kopułą.

Artykuł odnosi się pośrednio do zagadnienia odradzania się polskości na Ukrainie południowo-wschodniej. Najważniejszym czynnikiem, jaki wpłynął na poczucie tożsamości na terytorium Ukrainy (nie tylko Przyazowia), była wynaradawiająca polityka Rosji radzieckiej. Pod jej wpływem trudno było uniknąć wykształcenia się tożsamości homo sovieticus, człowieka pozbawionego osobowości, całkowicie podporządkowanego władzy, „człowieka gotowego do nieustannych i dobrowolnych samookaleczeń umysłowych” (Kołakowski 1989: 867). Jako dodatkowy aspekt tej polityki należy też wskazać wyraźnie widoczną w pamięci kulturowej Polonii południowo-wschodniej Ukrainy lukę pokoleniową, swoistą „utratę” pamięci, często odnotowywaną w warunkach kolonialnych. Ludzie żyjący w rozproszeniu, pozbawieni swojego kulturowego dziedzictwa, a często także wiedzy o swych przodkach, pozostawali w ciągłym kontakcie $z$ inną kulturą. Żyjący w multikulturowym tyglu za istotną rzecz postrzegali znalezienie i ocalenie śladów polskości na tych terenach, aby nie tylko wzmocnić (a może na nowo stworzyć) związek międzypokoleniowy, ale też kształtować tożsamość kulturową nowego pokolenia. Kościół w Dnieprze stanowi świadectwo tego, iż architektura sakralna jest istotnym elementem pamięci kulturowej dla Polaków na Ukrainie. Buduje ona poczucie własnej polskości i wyjątkowości w multikulturowym społeczeństwie. Burzliwe losy historyczne sprawiły, że religijność mniejszości polskiej na południowo-wschodniej Ukrainie znacznie różni się od religijności Polaków - katolików żyjących w jednorodnych wyznaniowo 
społecznościach - czy to w Polsce, czy na zachodzie Ukrainy. Brak obecności kościoła oraz religii w czasach radzieckich, zlikwidowanie samej instytucji religijnej, utrudnienie dostępu do wiedzy historycznej i fizyczne niszczenie obiektów sakralnych miały duży wpływ na tożsamość mieszkańców tamtych terenów. Wygrana walka o kościół pokazuje, że zabudowa sakralna, pomimo iż pozostawała długi czas zamknięta, a następie przebudowana, wzbudzała pamięć historyczną mieszkańców i wpływała na ich świadomość. Wiedza historyczna jest potrzebna do budowania tożsamości i potwierdzają to zdecydowane wysiłki wielu pokoleń walczących o jej zachowanie i przekazywanie nawet za cenę życia. Warto, aby mniejszości zarówno religijne, jak i narodowościowe wspierały działania na rzecz zachowania pamięci historycznej, ponieważ jest to nierozłączny element walki o tożsamość. Możliwość powrotu do kulturowych źródeł tożsamości, jaka zaistniała po odzyskaniu niepodległości przez Ukrainę, zrodziła możliwość badań, odrodzenia i rozpowszechnienia kultury polskiej w wielokulturowej strukturze południowo-wschodniej Ukrainy.

\section{BIBLIOGRAFIA}

Antonenko, N. (2019). Monument of modern architecture in the context of architectural culture of the second half of the twentieth century. Praca doktorska. Charków.

Antonenko, N. (2020). Ochrona zabytków architektury nowoczesnej na Ukrainie (1990-2010). Wiadomości Konserwatorskie, 62, 7-15.

Babiński, G. (2005). Tożsamość na pograniczach. W: E. Budakowska (red.), Tożsamość bez granic. Współczesne wyzwania (s. 103-104). Warszawa.

Bokszański Z., Tożsamości zbiorowe, Warszawa 2015.

Bonusiak A., Czop, E. (2014). Raport sytuacji Polonii i Polaków za granicą 2009, Warszawa 2009; Raport sytuacji Polonii i Polaków za granicą 2012, Warszawa 2013. Polityka i Społeczeństwo, 1(12).

Cherkasova, E. (2008). The public value of the architectural heritage of the Soviet avant-garde. Methods of preserving objects of architecture and urban planning. Problems Of Theory And History Of Architecture, 8, 128-135.

Czaban, M. (2007). Rodzina architektów Brodnickich w Jekaterynosławiu. Pobrane z: http:// www.sicheslav.porogy.org/2007/13/historyland/ (dostęp: 25.03.2021).

dombrovskii_a. (2012). Kazanskaja cerkow (Woznesenskaja). Namolennye mesta w Ekaterinoslawe. Pobrane z: https://www.shukach.com/ru/node/15955 (dostęp: 25.03.2021).

Dyomin, M., Ivasho, Y. (2020). Specyfika stylistyczna zabudowy historycznej okresu secesji (na przykładzie Połtawy). Wiadomości Konserwatorskie, 62, 79-84.

Dyomin, N. (2015). Tworczist architektora Horodeckogo w kontekste epochi „Kiewskogo” modernu. Materiały VI wseukrainskoi naukowoi konferencji: suczasna architekturna oswita: 
architektura, obraz, estetyka, emocijny kontekst. Kijów: Kijowski Narodowy Uniwersytet Budownictwa i Architektury.

Dzwonkowski, R. (2000). Polacy w kościele na wschodzie - przemiany i problemy. W:

T. Gęsowski (red.), Państwo polskie wobec Polaków na Wschodzie. Poszukiwanie modelu polityki (s. ). Kraków.

Gonczenko, T. (2013). Rekonstrukcja katoliceskogo kostela zawersitsa w sentjabre. Pobrane z: https://gorod.dp.ua/news/79417 (dostęp: 31.05.2020).

Gonczarowa, K. (2015). Wykorystanna elementiw z riznych architekturnych stylej u tworczosti Władysława Horodeckiego. Materiały VI wseukrainskoi naukowoi konferencji: suczasna architekturna oswita: architektura, obraz, estetyka, emocijny kontekst. Kijów: Kijowski Narodowy Uniwersytet Budownictwa i Architektury.

Gorodczenko, W. (2015). Dnieproprtrowskomu pocztamtu -110 let. Pobrane z: https://gorod. dp.ua/news/112326 (dostęp: 24.02.2020).

Gubkina, Y. (2020). Soviet modernism. Brutalism. Post-modernism (Buildings and structures in Ukraine 1955-1991). Kyiv.

Ivasho Y., Orlenko, M. (2019). The concept of art and works of art in the theory of and in the restoration industry. Art Inquiry. Recherches sur les arts, 21, 171-190. https://doi. org/10.26485/Al/2019/21/12

Ivasho, Y. (2015). „Budynok z himerami” w switowij spadszczyni stylu modern: architekturni paraleli. Materiały VI wseukrainskoi naukowoi konferencji: suczasna architekturna oswita: architektura, obraz, estetyka, emocijny kontekst. Kijów: Kijowski Narodowy Uniwersytet Budownictwa i Architektury.

Kołakowski, L. (1989). Główne nurty marksizmu. Tom III. Warszawa: Krąg/Pokolenie.

Kondel-Perminova, N. (2009). Preservation of architectural and urban heritage of Ukraine in the context of urban development. Modern Problems of Research, Restoration and Preservation of Cultural Heritage, 6, 92-116.

Korowkina, A. (2015). W.W. Horodeckij- jak architektor - nowator rubeża stolit. Materiały VI wseukrainskoi naukowoi konferencji: suczasna architekturna oswita: architektura, obraz, estetyka, emocijny kontekst. Kijów: Kijowski Narodowy Uniwersytet Budownictwa i Architektury.

Krasowska, H. (2012). Mniejszość polska na południowo-wschodniej Ukrainie. Warszawa.

Księga pamiq̨tkowa Inżynierów Cywilnych Polaków wychowanków Instytutu Inżynierów Cywilnych w Petersburgu. (1937). Warszawa: nakł. Koło Inżynierów Cywilnych przy Stow. Techn. Pol.

Mucha, J. (1996). Codzienność i odświętność. Polonia w South. Warszawa.

Współczesna edukacja architektoniczna: architektura, estetyka, kontekst. (2015). Materiały pokonferencyjne VI Ogólnoukraińskiej Konferencji Naukowej z okazji 150 rocznicy urodzin W. Horodeckiego. Kijów: Kijowski Narodowy Uniwersytet Budownictwa i Architektury. 
Omilanowska, M., Bilewicz, H. (2013). Architektura, polityka, tożsamość: z badań nad karierami polskich wychowanków rosyjskich uczelni architektonicznych w XIX i na początku XX wieku (casus Józefa Padlewskiego). W: J. Malinowski, I. Gavrash, N. Mizerniuk-Rotkiewicz (red.), Polska-Rosja. Sztuka i historia. Sztuka polska, sztuka rosyjska i polsko--rosyjskie kontakty artystyczne do poczatku XX wieku (s. 300). Warszawa-Toruń.

Pavliuk, O. (2019). Mozaika etniczna Ukrainy południowo-wschodniej - wzmianka historyczna na przykładzie Zaporoskiego Przyazowia. Postscriptum polonistyczny, 2(24), 205-213.

Polakowa, J. (2014). Architekci Charkowa polskiego pochodzenia. W: Polska diaspora w Charkowie. Historia i współczesność (s. 136). Charków.

Remeshylo-Rybchynska, O., Baev, A., Rybchynsky, A. (2013). On the problem of preserving the heritage of residential architecture of functionalism in Lviv. Bulletinof the National University Lviv Polytechnic, 757, 310-314.

Ricoeur, P. (1992). Tożsamość osobowa. W: Filozofia osoby, przeł. M. Frankiewicz. Kraków.

Smolenskaya, S. (2017). Architecture of avant-garde modernism in Ukraine: genesis and heritage. Charków.

Starostin, W. (2011a). Polska rodzina jekaterynosławskich architektów. Pobrane z: http:// archive.li/7BBuj\#selection-1217.0-1417.30_(dostep: 25.03. 2021).

Starostin, W. (2011b). Rzymsko-katolicki kościół w Jekaterynosławiu. Chram pw. św. Josypa. Pobrane z: https://www.shukach.com/ru/node/889 (dostęp: 15.10.2020).

Starostin, W. (2020). W Dniepre udaloś soxranit starejsyj katoliceskij xram. Pobrane z: https:// vesti.dp.ua/v-dnepre-udalos-sohranit-starejshij-katolicheskij-hram/ (dostęp: 18.06.2020).

Suchomłynow, L. (2008). Kresy południowo-wschodnie: dwie perspektywy dyskursu. Fenomen pogranicz kulturowych: współczesne tendencje. Donieck.

Szrub, K. (2019). Ludzie Dniepru: architekci Brodniccy. Pobrane z: https://gorod.dp.ua/ news/168079 (dostęp: 24.12.2020).

Vesel, P. (2013). Architectural heritage of Ukraine of the Soviet period, the criteria for recognizing its objects as „monuments" and the chances of state protection. Urban Planning and Spatial Planning, 64, 87-95. 
